\title{
ANALISIS DAN PERANCANGAN SISTEM INFORMASI MANAJEMEN DI KLINIK PRATAMA BSMI KLATEN
}

\author{
Muhammad Khulaimi, Ari Andriyas Puji, Winda Nur Cahyo \\ Program Studi Magister Teknik Industri Universitas Islam Indonesia \\ Jl. Kaliurang Km 14,5 Yogyakarta 55584 \\ Email: mhulaimi.com@gmail.com, andriyasari@umri.ac.id, winda.nurcahyo@uii.ac.id
}

\begin{abstract}
Clinic is a health service facility that organizes individual health services that provide basic and specialized medical services, is organized by more than one type of health worker and is led by a medical staff (Menkes RI, 2001).

Clinic Pratama BSMI Klaten is an institution engaged in the field of health services that provides quality basic health services. Present as a follow-up to the post-earthquake service process in Yogayakarta-Central Java on May 26, 2006 Inaugurated on November 13, 2006 by the Chairperson of the MPR. RI Dr. Hidayat Nurwahid, MA and the general chairman of BSMI DR.dr. H. Basuki Supartono, SP.OT, FICS, MARS.

So far, the recording of patient medical records at the BSMI Klaten Primary Clinic is still using book media. This means that all these activities are carried out without the assistance of a computer so that it can result in lost or lost clinical records of various data. This, according to the author, is still very ineffective because it makes it difficult when presenting data such as an example of presenting data on treatment history or medical records for each patient which will take a long time.

To overcome this problem, an information system that is able to provide fast information to patients and the public is needed. In order to improve services and improve the performance of each unit which is interconnected and integrated.

Analysis and design of management information systems at the BSmi Klaten Pratama clinic which was made using the PHP programming language and the server using MySQL. The designed process consists of a registration unit, an initial examination of the patient by a nurse, a doctor's examination, a medical support unit, a pharmacy and a cash payment system, each of which can be data-integrated in a Clinical Management information system.
\end{abstract}

Keywords: Health Services, Management Information Systems, Clinical Management Information Systems, Clinic BSMI Klaten, PHP.

\section{Abstrak}

Klinik adalah fasilitas pelayanan kesehatan yang menyelenggarakan pelayanan kesehatan perorangan yang menyediakan pelayanan medis dasar dan spesialistik, diselenggarakan oleh lebih dari satu jenis tenaga kesehatan dan dipimpin oleh seorang tenaga medis (Menkes RI, 2001).

Klinik Pratama BSMI Klaten adalah Institusi yang bergerak dalam bidang pelayanan kesehatan yang menyediakan layanan kesehatan dasar yang bermutu. Hadir sebagai tindak lanjut dari proses pelayanan pasca bencana gempa bumi di Yogayakarta-Jawa Tengah tanggal 26 Mei 2006 Diresmikan pada tanggal 13 November 2006 oleh Ketua MPR. RI Dr. Hidayat Nurwahid, MA. dan ketua umum BSMI DR.dr. H. Basuki Supartono, SP.OT, FICS, MARS.

Selama ini pencatatan perawatan rekam medis pasien di Klinik Pratama BSMI Klaten masih menggunakan media buku. Artinya semua kegiatan itu dilakukan tanpa bantuan komputer sehingga dapat mengakibatkan catatan-catatan berbagai data klinik hilang atau. Hal ini menurut penulis masih sangat kurang efektif karena edis tiap pasien akan memakan waktu yang cukup lama. 
Untuk mengatasi masalah tersebut diperlukan sebuah sistem informasi yang mampu memberikan informasi yang cepat kepada pasien dan masyarakat. Guna meningkatkan pelayanan dan peningkatan kinerja masing-masing unit yang saling berhubungan dan terintegrasi.

Analisis dan perancangan sistem informasi manajemen di klinik pratama Bsmi Klaten yang dibuat menggunakan bahasa pemrograman PHP dan server menggunakan MySQL. Proses yang dirancang terdiri dari unit pendaftaran, pemeriksaan awal pasien oleh perawat, pemeriksaan dokter, unit penunjang medis, apotek dan sistem pembayaran dikasir, masing-masing modul tersebut dapat saling terintegrasi secara data dalam sebuah sistem informasi Manajemen Klinik.

Kata kunci: Pelayanan Kesehatan, Sistem Informasi Manajemen, Sistem Informasi Manajemen Klinik, Klinik BSMI Klaten, PHP.

\section{PENDAHULUAN}

Sistem informasi merupakan salah satu penunjang dari majunya suatu perusahaan. Pada organisasi modern keberadaan sistem informasi manajemen sangat diperlukan bahkan hingga tingkat urgent. Sistem informasi manajemen sudah menjadi bagian yang tidak terpisahkan dari keberjalanan manajemen organisasi/perusahaan.

Klinik sebagai salah satu institusi pelayanan umum membutuhkan keberadaan suatu sistem informasi yang cepat, tepat akurat serta cukup memadai untuk meningkatkan pelayanan kepada para pasien serta pihak yang terkait di dalamnya.

Klinik Pratama BSMI Klaten adalah Institusi yang bergerak dalam bidang pelayanan kesehatan yang menyediakan layanan kesehatan dasar yang bermutu. Hadir sebagai tindak lanjut dari proses pelayanan pasca bencana gempa bumi di Yogayakarta-Jawa Tengah tanggal 26 Mei 2006 Diresmikan pada tanggal 13 November 2006 oleh Ketua MPR. RI Dr. Hidayat Nurwahid, MA. dan ketua umum BSMI DR.dr. H. Basuki Supartono, SP.OT, FICS, MARS. Saat ini jumlah pasien sudah mencapai 26.522 pasien yang tercatat sejak berdirinya pada tahun 2016 lalu dan statusnya masih aktif dan rutin melakukan kontrol. Oleh seabab itu dibutuhkan sistem informasi untuk merekam riwayat perawatan (Rekam Medis) dari setiap pasien yang berkunjung.

Selama ini pencatatan perawatan rekam medis pasien di Klinik Pratama BSMI Klaten masih menggunakan media buku. Artinya semua kegiatan itu dilakukan tanpa bantuan komputer sehingga dapat mengakibatkan catatan-catatan berbagai data klinik hilang. Sistem rekam medis adalah suatu sistem yang bertujuan untuk mendokumentasikan data-data medis pasien. Sistem ini akan mencatat, mengolah dan kemudian menyajikan data-data yang berhubungan dengan hal-hal medis. misalnya data pasien, riwayat kesehatan pasien, bahan yang digunakan untuk restorasi, obat apa saja yang sudah diberikan sampai besarnya biaya yang harus dibayar dan lain-lain.
Dilihat dari latar belakang masalah tersebut, Sistem informasi Manajemen dirasa perlu dan dibutuhkan untuk mempermudah dalam mendapatkan informasi tentang klinik, pencarian data pasien, pengolahan data, mengontrol persediaan alat yang digunakan untuk restorasi, serta memantau perkembangan perawatan tiap pasien. Dengan mempertimbangkan permasalahan yang ada, penulis memberikan solusi dengan membangun aplikasi Analisis dan Perancangan Sistem Informasi Manajemen pada klinik Pratama BSMI Klaten.

\subsection{Rumusan Masalah}

Dari latar belakang masalah di atas, maka rumusan masalah pada penelitian ini adalah:

1) Bagaimana cara merancang dan membangun sistem informasi Manajemen pada Klinik Pratama BSMI Klaten

2) Bagaimana Sistem Informasi Manajemen dapat membantu proses bisnis pada Klinik Pratama BSMI Klaten

\subsection{Kajian Pustaka}

\subsubsection{Klinik}

Berdasarkan peraturan Menteri Kesehatan Republik Indonesia Nomor 028/Menkes/Per/I/2011, pengertian klinik adalah fasilitas pelayanan kesehatan yang menyelenggarakan pelayanan kesehatan perorangan yang menyediakan pelayanan medis dasar dan spesialistik, diselenggarakan oleh lebih dari satu jenis tenaga kesehatan dan dipimpin oleh seorang tenaga medis (Menkes RI, 2001).

\subsubsection{Rekam Medis}

Rekam medis merupakan arsip yang didalamnya berisi catatan-catatan dan dokumen tentang identitas pasien, riwayat pemeriksaan pasien, pengobatan pasien, tindakan dan pelayanan lain yang diberikan kepada pasien (Kementerian Kesehatan, 2008).

\subsubsection{Sistem Informasi Manajemen}

SIM (Sistem Informasi Manajemen) dapat didefenisikan sebagai kumpulan dari interaksi 
sistem-sistem informasi yang bertanggung jawab mengumpulkan dan mengolah data untuk menyediakan informasi yang berguna untuk semua tingkatan manajemen di dalam kegiatan perencanaan dan pengendalian. (Pangestu,2007).

\subsection{Tinjauan Pustaka}

Galouh Maya Liasarie (2017), penelitian berjudul "Sistem Informasi Manajemen Klinik Bersalin Nurani Godean Sleman Yogyakarta".

Rahmadani (2015), pada penelitian berjudul "Analisis dan Perancangan Sistem Informasi Manajemen Keuangan Rumah Sakit Daerah Sawerigading Kota Palopo (Studi Kasus pada Pada Rumah Sakit Umum Daerah Sawerigading Kota Palopo Provinsi Sulawesi Selatan)".

Muhamad Kurniawan Akbar (2013) pada penelitian berjudul "Sistem Informasi Manajemen pada rumah sakit khusus paru-paru Palembang".

\subsection{Metodologi Penelitian}

Sistem Informasi Klinik ini dibangun menggunakan metode pendekatan waterfall dalam pengembangan perangkat lunak sistemnya. Hal ini dikarenakan pengembangan sistem menggunakan pendekatan secara sistematis dan dilakukan secara bertahap.

\subsection{Metode Pengumpulan Data}

Metode pengumpulan data yang digunakan dalam penelitian ini, yaitu dengan cara Studi Literatur, Studi Wawancara, dan Observasi

\section{Analisis dan Perancangan}

\subsection{Proses Bisnis}

Proses bisnis yang sedang berjalan di Klinik Pratama BSMI Klaten terbilang masih sangat sederhana, semua kegiatan pelayanan pasien yang berjalan saat ini masih menggunakan pencatatan manual menggunakan kertas baik itu pencatatan rekam medis pasien, pencatatan obat obatan, kasir maupun keuangan.

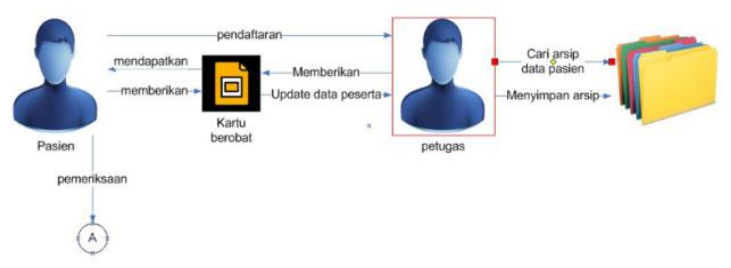

Gambar 1. Proses Registrasi dan Update Data Pasien

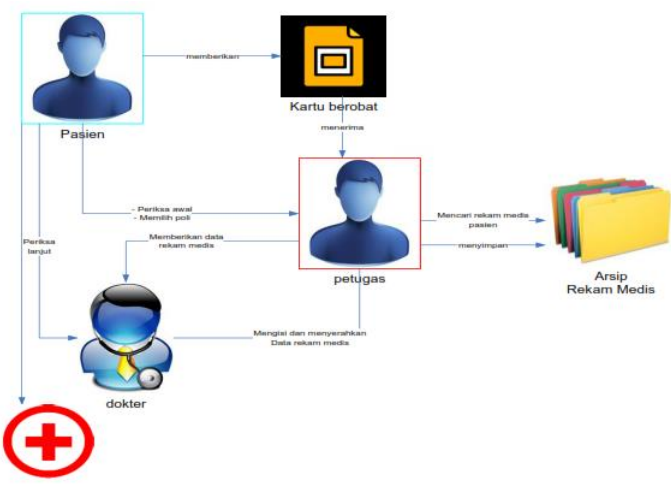

Gambar 2 Proses Rekam Medis

\subsection{Perancangan Sistem}

\subsubsection{Perancangan Data Flow Diagram}

Data flow diagram (DFD) sering digunakan untuk menggambarkan suatu sistem yang telah ada atau sistem baru yang akan dikembangkan secara logika tanpa mempertimbangkan lingkungan fisik dimana data tersebut mengalir, atau lingkungan fisik dimana data tersebut tersimpan.

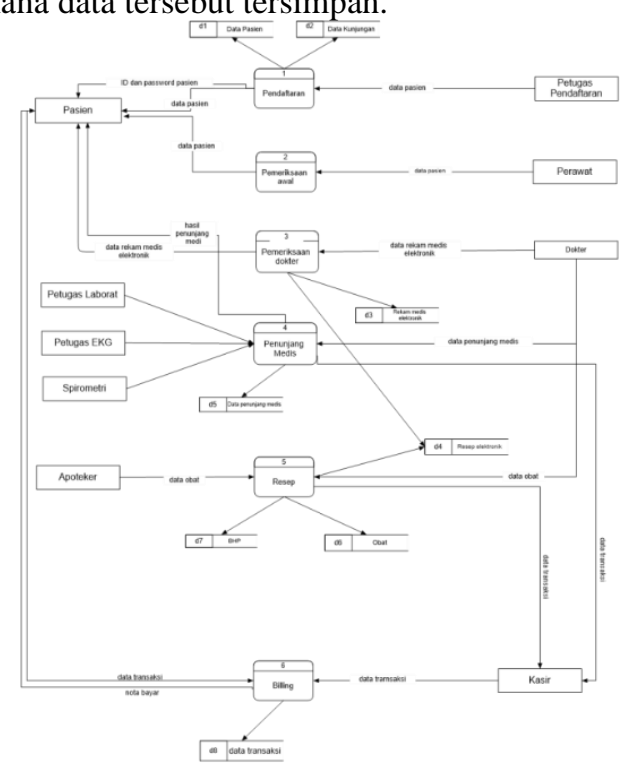

Gambar 3. DFD lv 0 Sistem 

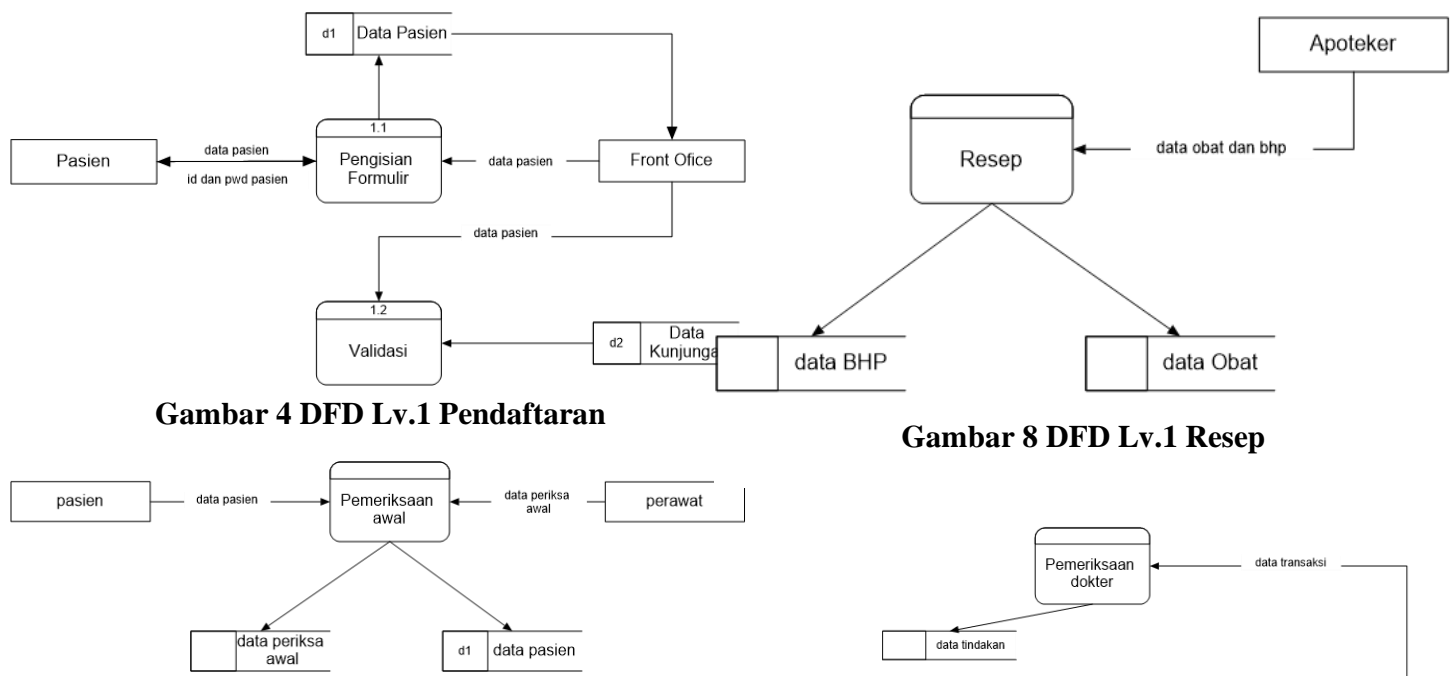

perawat

Gambar 5 DFD Lv.1 Periksa Awal

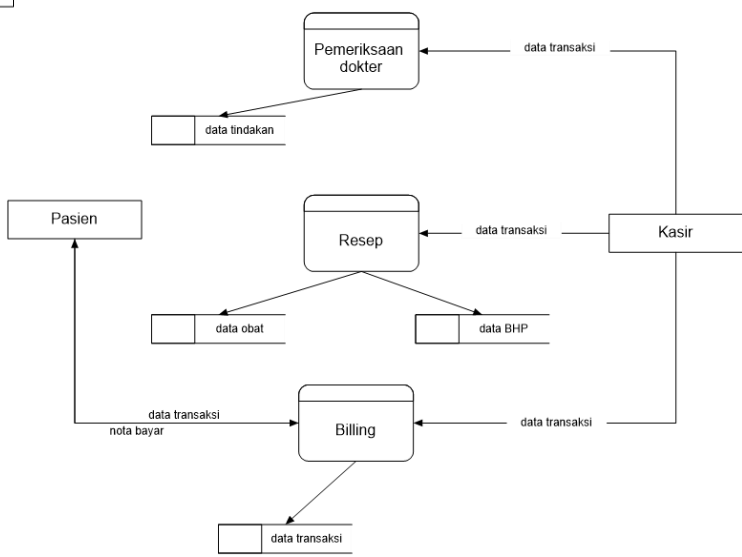

Gambar 9 DFD Lv.1 Billing

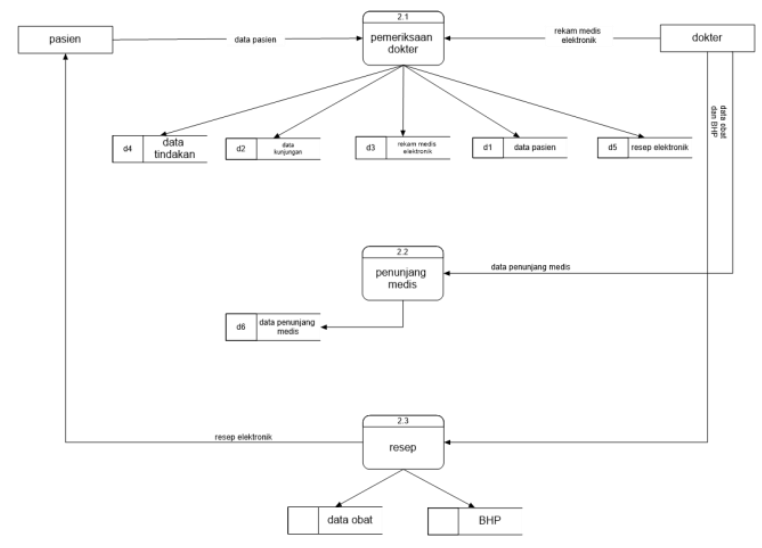

Gambar 6 DFD Lv.1 Pemeriksaan Dokter

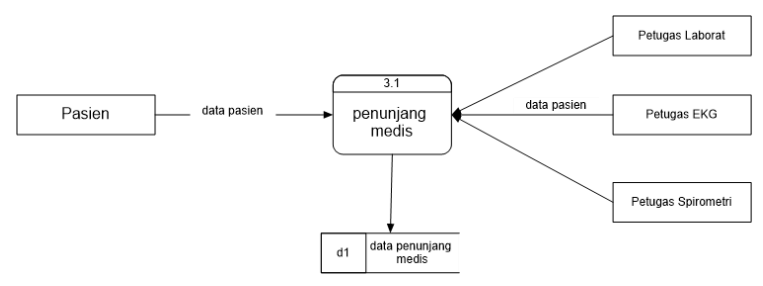

2.2.2. Perancangan Database Sistem

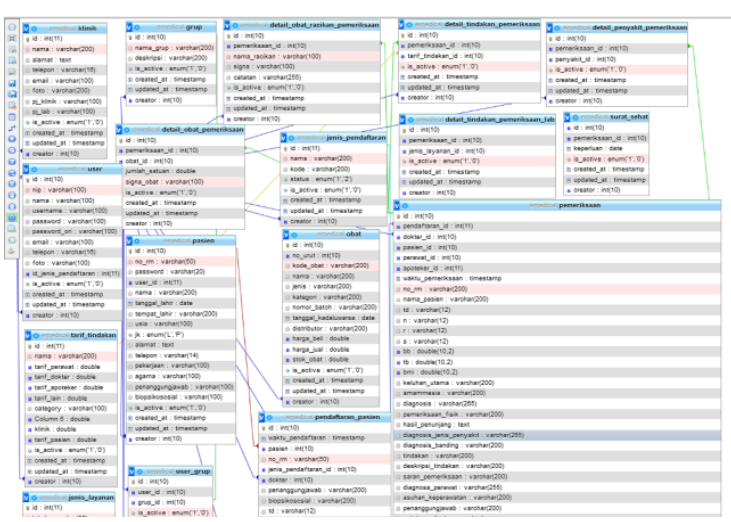

Gambar 10 Database Sistem 1

Gambar 7 DFD Lv.1 Penunjang Medis

SURYA TEKNIKA Vol. 8 No. 1, Juni 2021: 252-261 


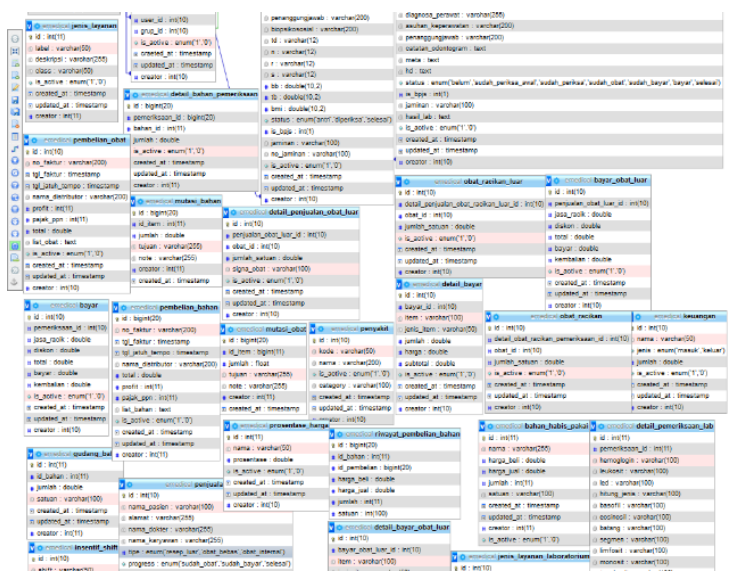

Gambar 11 Database Sistem 2

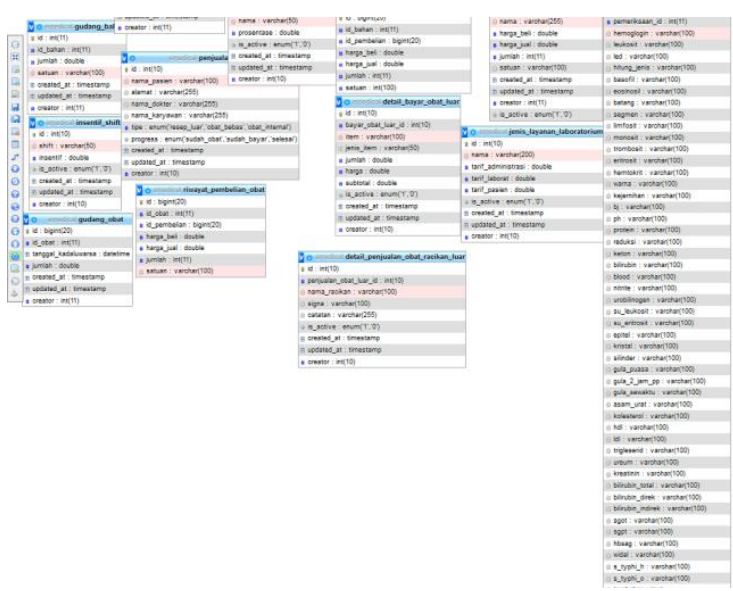

Gambar 12 Database Sistem 3

\section{Hasil Pembahasan}

\subsection{Implementasi}

Tahap implementasi pada bab ini merupakan hasil realisasi dari perancangan yang telah dibuat kedalam sistem yang sebenarnya. Hal ini untuk memastikan bahwa perangkat lunak yang diciptakan sesuai dengan rencana. Adapun tampilan hasil implementasi sebagai berikut.

\subsubsection{Halaman Login}

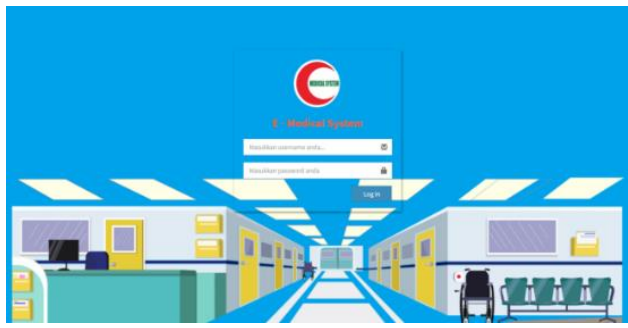

Gamgar 13 Halaman Login
Halaman yang digunakan untuk user melakukan login ke dalam sistem informasi Emedical Sistem seperti gambar 13.

\subsubsection{Halaman Dashboard Admin}
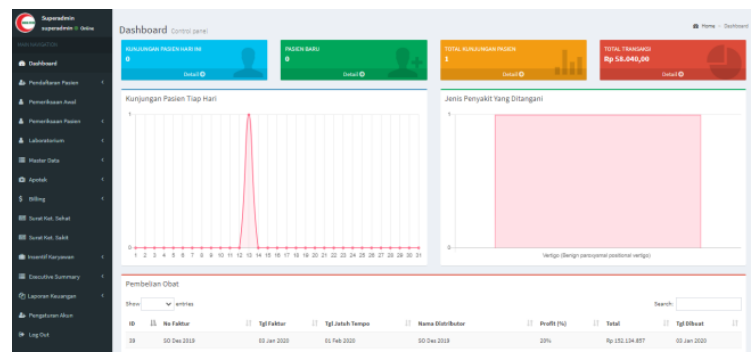

Gambar 14 Halaman Dashboard Admin

Halaman dashboard user dengan level admin melakukan pengelolahan data dalam sistem informasi manajemen Emedical Sistem pada gambar 14.

\subsubsection{Halaman Dashboard Front Office}

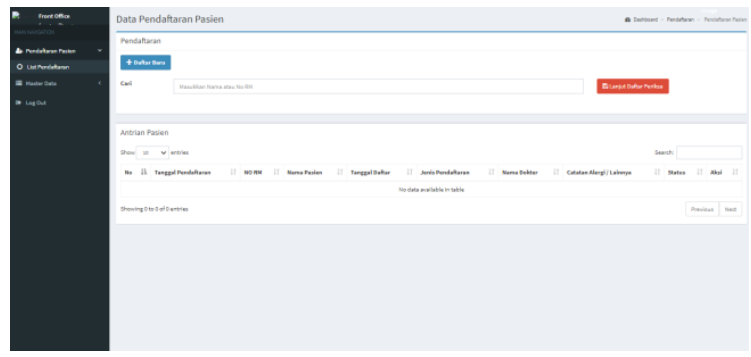

Gambar 15. Halaman Pendaftaran Pasien Baru

Halaman dashboard dengan level user Front Office ini berfungsi untuk mendaftarkan pasien, baik pasien baru maupun pasien lama seperti pada gambar 15 .

Dalam halaman ini terdapat tools-tools yang bisa dioperasikan oleh petugas front office.

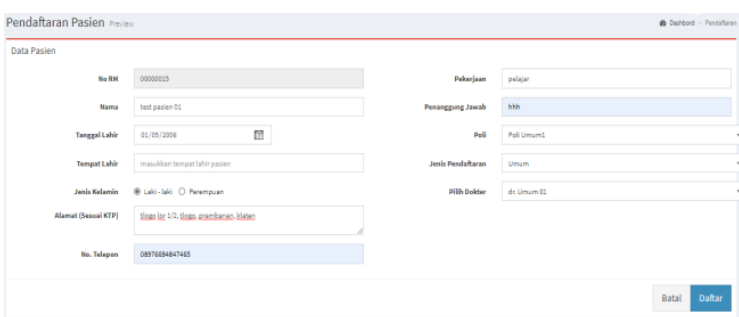

Gambar 16 Pendaftaran Pasien Baru

Daftar baru yang berfungsi untuk menambahkan data antrian pasien yang baru 
pertama kali periksa ke klinik seperti pada gambar 16.

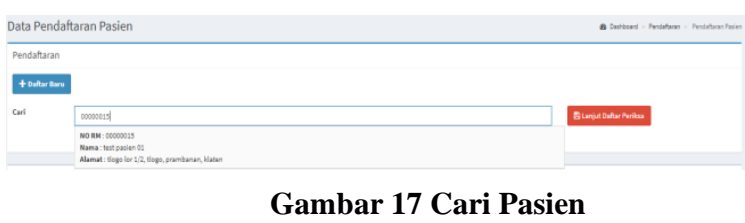

Kolom cari yang berfungsi untuk mencari data pasien lama dengan cara memasukkan nomor rekam medis atau nama pasien tersebut seperti pada gambar 17.

\subsubsection{Halaman Dashboard Perawat}

Halaman dengan level user perawat merupakan halaman yang hanya bisa diakses oleh perawat, dalam halaman ini terdapat beberapa fungsi

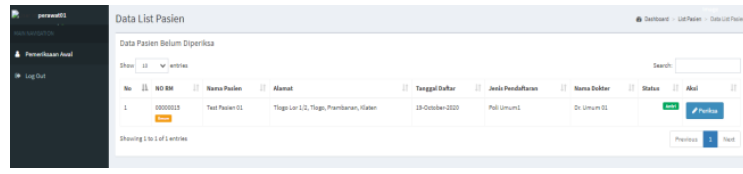

\section{Gambar 18 List Pasien Periksa Awa}

Pemeriksaan Awal, pada fungsi ini akan ditampilkan antrian data list pasien yang sudah daftar untuk periksa seperti pada Gambar 18.

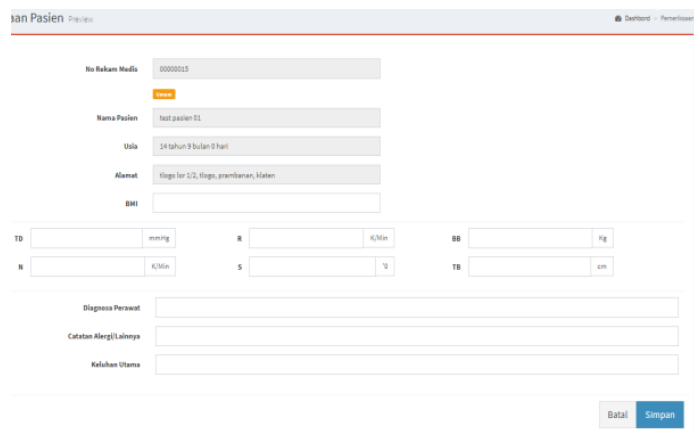

Gambar 19 Pemeriksaan Awal Pasien

\subsubsection{Halaman Pemeriksaan Dokter}

Halaman dengan level user dokter terdapat tampilan dashboard yang akan menampilkan menu menu sebagai berikut :
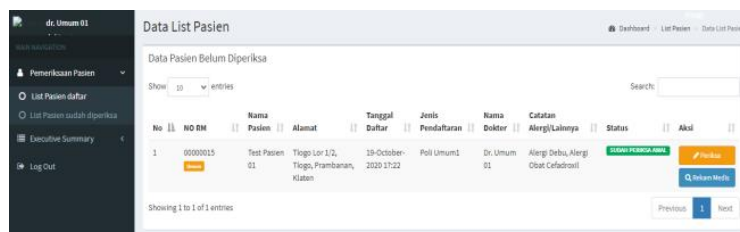

Gambar 20 halaman dokter list pasien daftar akan menampilkan list pasien yang akan diperiksa oleh dokter seperti pada gambar 20. Terdapat dua tombol yaitu periksa dan rekam medis.

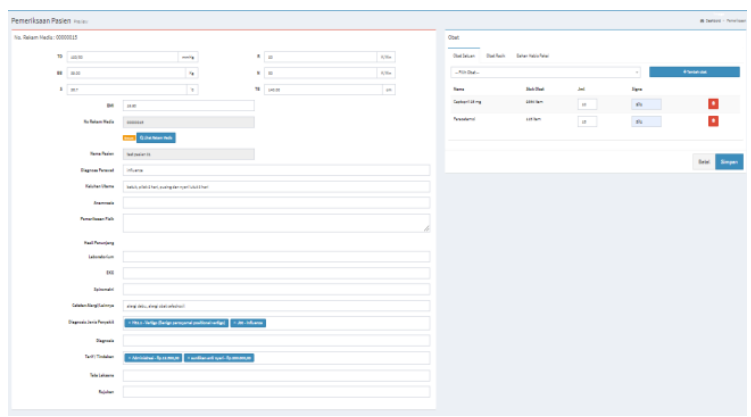

Gambar 21 Halaman Pemeriksaan Pasien

Tombol periksa yang berfungsi untuk menuju halaman pemeriksaan pasien seperti pada gambar 21.

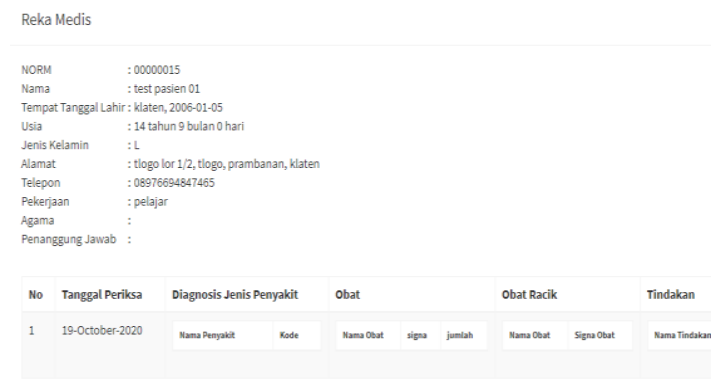

Gambar 22 Rekam Medis Pasien

Tombol rekam medis yang berfungsi untuk melihat riwayat pemeriksaan pasien sebelumnya seperti pada gambar 22 .

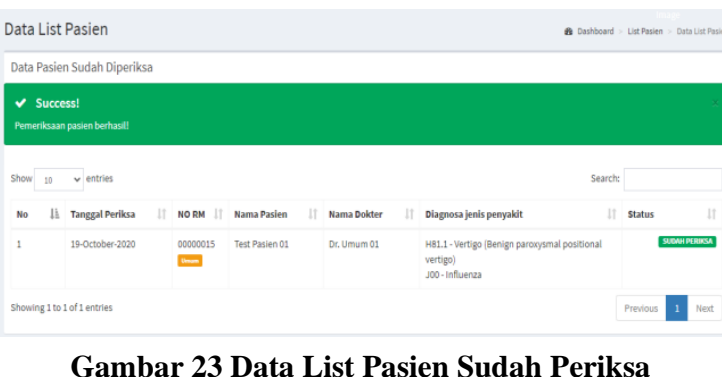

Menu List pasien sudah periksa akan menampilkan data pasien yang sudah selesai diperiksa oleh dokter seperti pada gambar 23. 


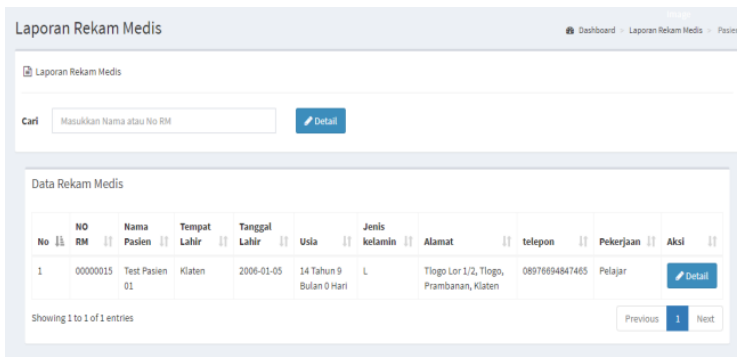

Gambar 24 Laporan Rekam Medis

Tools executive Summary pada halaman dokter berfungsi untuk melihat data rekam medis pasien yang diinginkan seperti pada gambar 24 .

\subsubsection{Halaman Billing}

Halaman dengan level user billing terdapat menu dengan tampilan yang akan menampilkan menu menu sebagai berikut :
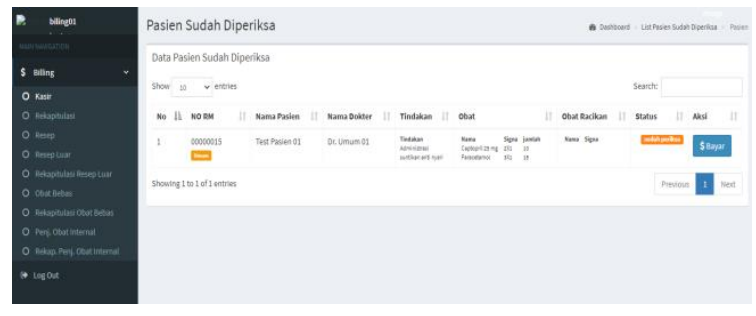

Gambar 25 Halaman Billing

Kasir yang berfungsi untuk menampilkan data list pasien sudah periksa seperti pada gambar 25 .

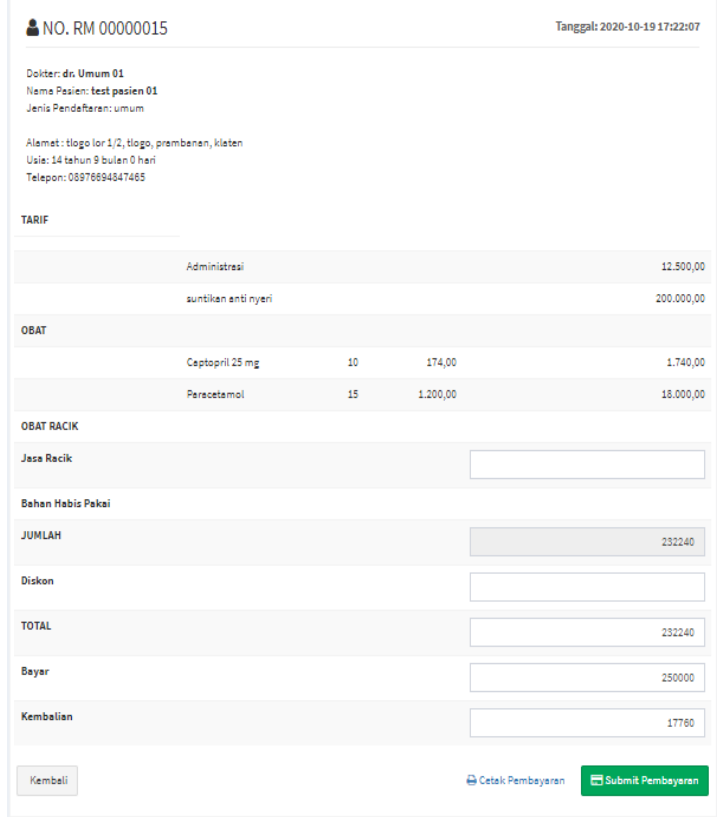

Gambar 26 Halaman Pembayaran
Pada menu Kasir terdapat tombol bayar yang berfungsi untuk masuk ke halaman pembayaran pasien yang sudah selesai diperiksa seperti pada gambar 26.

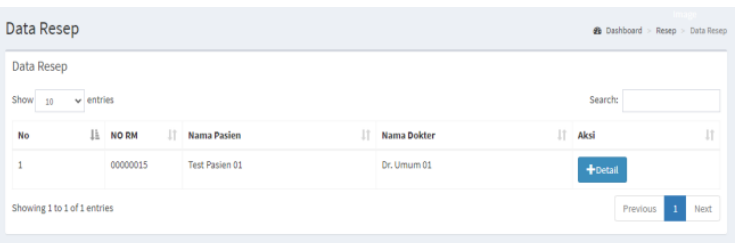

\section{Gambar 27 Data Resep}

Menu Resep berfungsi untuk melihat list pasien yang sudah selesai diperiksa oleh dokter untuk dilakukan peracikan obat seperti pada gambar 27

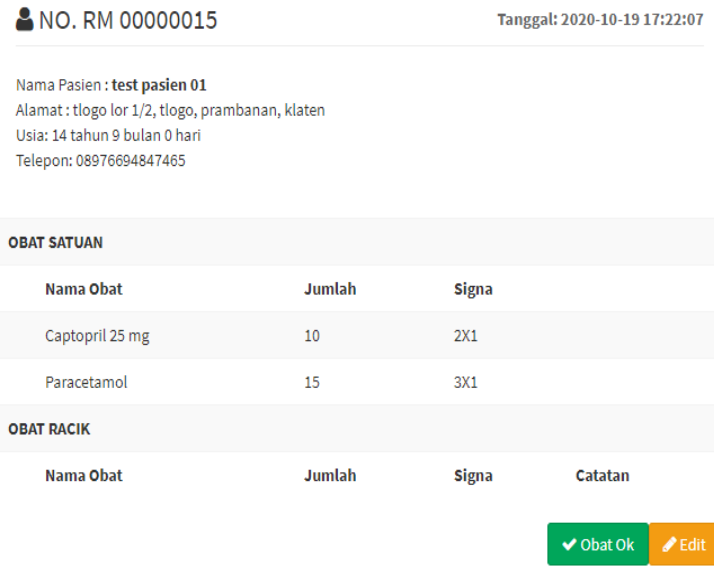

Gambar 28 Halaman Resep

Dalam menu resep terdapat tombol detail yang berfungsi untuk melihat detail resep obat yang sudah diresepkan dokter kepada pasien seperti pada gambar 28

\subsubsection{Halaman Kabag Farmasi}

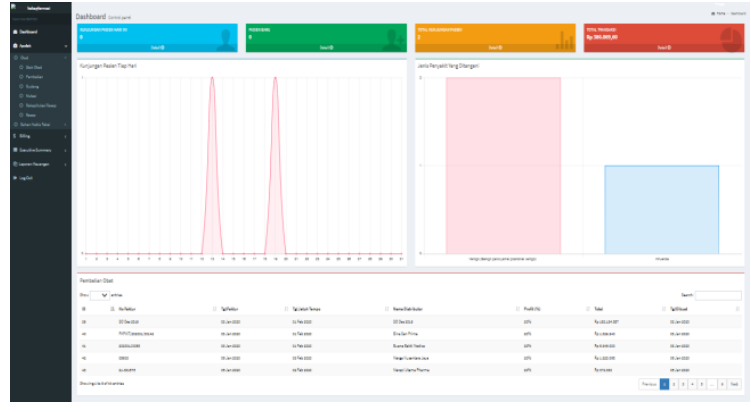

Gambar 29 Halaman Kabag farmasi 
Dashboard kabag farmasi berfungsi menampilkan data statistik kunjungan pasien hari ini, pasien baru, total kunjungan pasien, data transaksi. Selain itu dalam halaman dashboard akan menampilkan data pembelian obat dan data obat yang mendekati kadaluarsa.

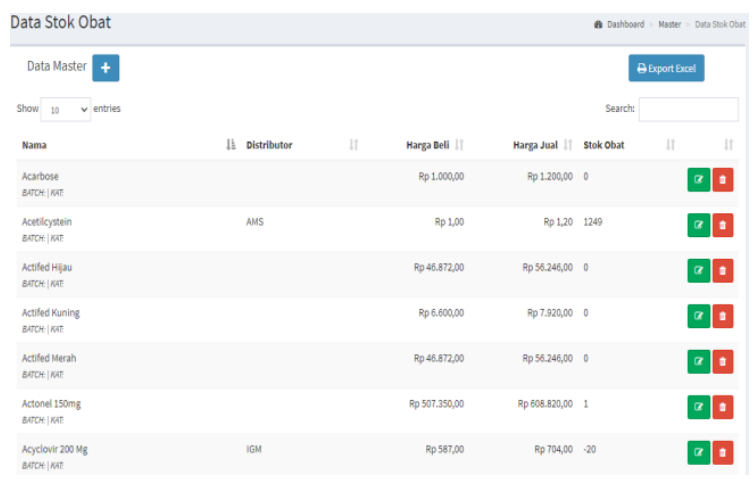

Gambar 30 Data Stok Obat

Stok obat yang berfungsi untuk menampilkan data stok obat yang ada di apotek.

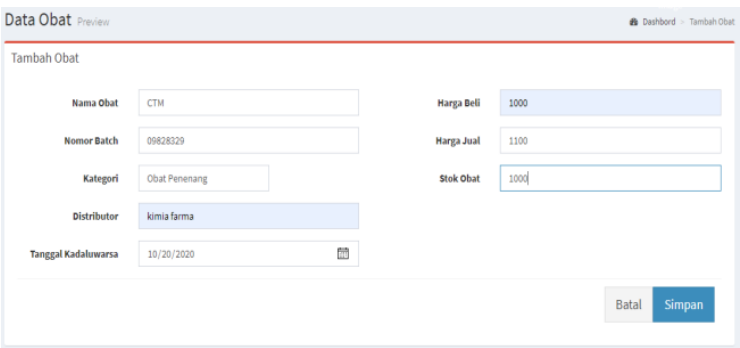

Gambar 31 Tambah Data obat

Dalam halaman data stok obat ada tombol data master tambah yang berfungsi untuk menambah data stok obat.

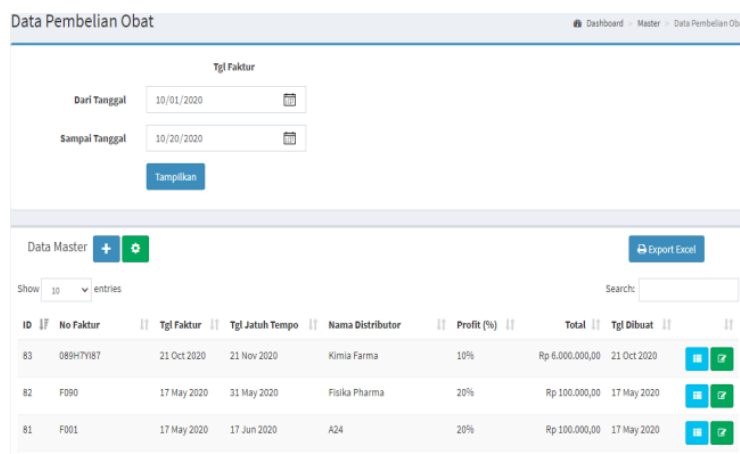

Gambar 32 Pembelian Obat

Pembelian yang berfungsi untuk menambah data pembelian obat dari distributor obat.

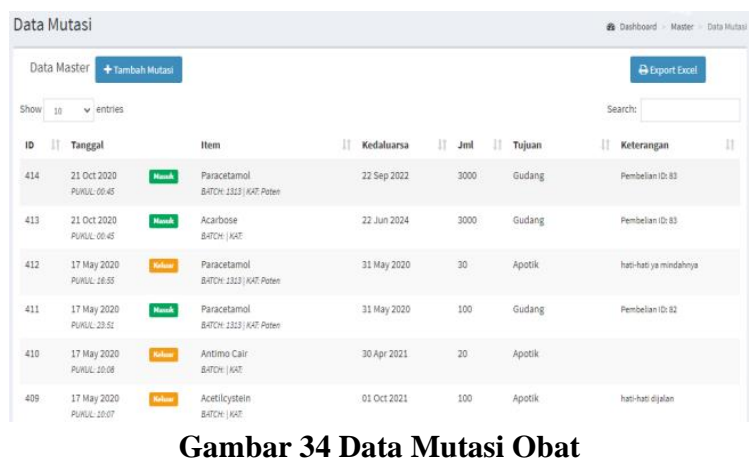

Menu mutasi berfungsi untuk mencatat perpindahan obat dari gudang obat ke apotek.

\subsubsection{Halaman Pasien}

Halaman dengan level user pasien berfungsi untuk melihat riwayat rekam medis pasien selama periksa di klinik, pasien bisa login ke halaman pasien menggunakan no rekam medis pasien dan password pasien yang telah diberikan oleh petugas front office.

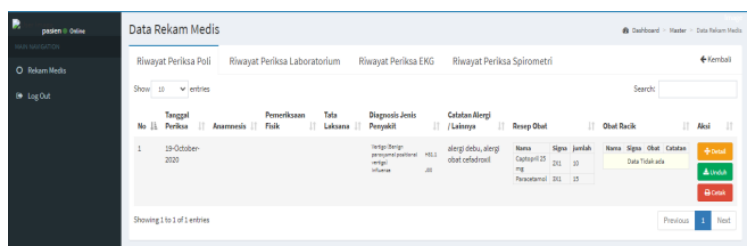

Gambar 35 Halaman Pasien

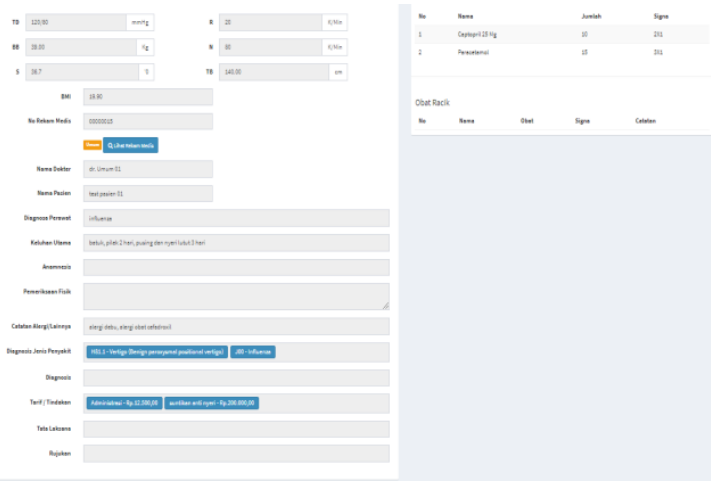

Gambar 36 Halaman Detail Pemeriksaan

\subsubsection{Halaman Executive Summary}

Pada user dengan level admin berfungsi untuk melihat performa klinik pada periode tertentu. Dalam halaman executive summary akan menampilkan menu menu :

a. Menu Kunjungan pasien yang berfungsi untuk melihat jumlah kunjungan pasien ke klinik pada peridoe tertentu. 


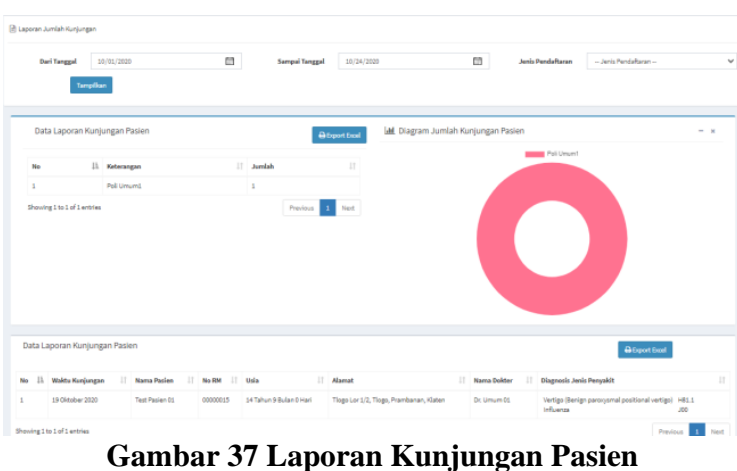

b. Menu Jumlah Pasien Baru

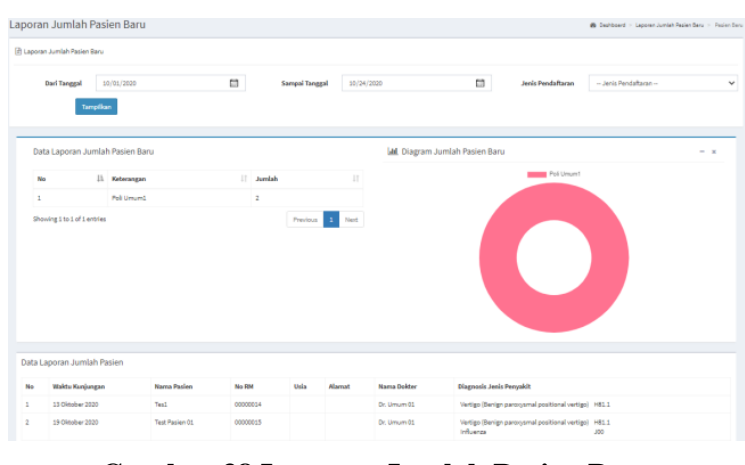

Gambar 38 Laporan Jumlah Pasien Baru

c. Menu rata-rata kunjungan pasien

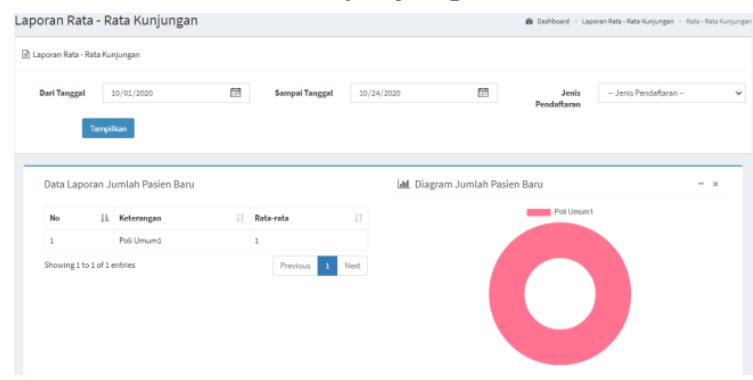

Gambar 39 Laporan Rata-Rata Kunjungan

\section{d. Menu rata-rata pasien}

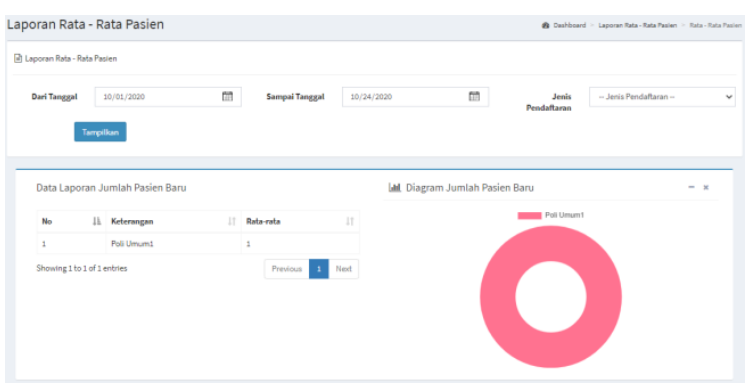

Gambar 40 Laporan Rata-Rata Pasien

e. Menu jenis penyakit yang berfungsi untuk melihat jenis penyakit apa saja yang sering diperiksa di klinik.

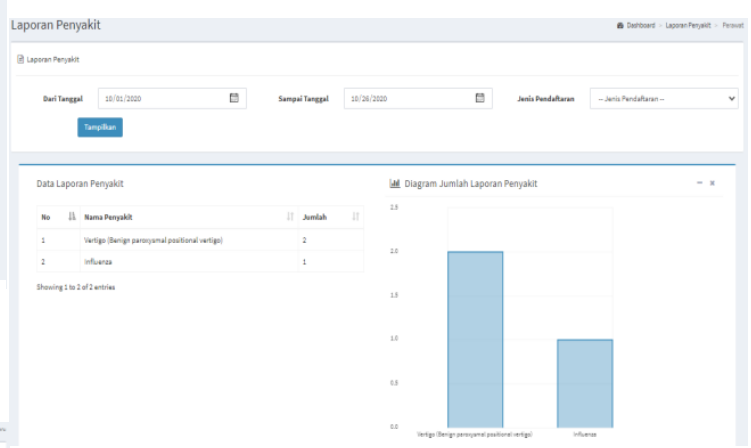

Gambar 41 Laporan Penyakit

\section{Kelebihan Sistem}

Kelebihan dari sistem informasi manajemen Klinik pratama BSMI Klaten, antara lain :

1. Sistem informasi manajemen Klinik Pratama BSMI Klaten mudah untuk digunakan.

2. Sistem Informasi manajemen Klinik Pratama BSMI Klaten sangat membantu kinerja.

3. Sistem informasi manajemen Klinik Pratama BSMI Klaten sangat membantu pengolahan data.

4. Sistem informasi manajemen Klinik Pratama BSMI Klaten mengurangi resiko kehilangan data.

5. Sistem informasi manajemen Klinik Pratama BSMI Klaten memiliki user account pasien untuk melihat data rekam medis pasien tanpa harus bertanya ke klinik.

\section{Kekurangan Sistem}

Kekurangan dari sistem informasi manajemen Pratama BSMI Klaten, antara lain :

1. Sistem informasi manajemen Klinik Pratama BSMI Klaten tampilan nya masih kurang menarik

2. Membutuhkan bimbingan untuk mengoperasikan sistem manajemen Klinik Pratama BSMI Klaten

3. Sistem informasi manajemen Klinik Pratama BSMI Klaten belum bisa digunakan di smart phone.

\section{Kesimpulan}

Dari hasil penelitian serta pembahasan sistem informasi Klinik Pratama BSMI Klaten yang telah dilakukan dapat disimpulkan bahwa : 
Telah berhasil membangun sistem informasi manajemen yang dapat menunjang proses bisnis di klinik Pratama BSMI Klaten dan mempermudah klinik Pratam BSMI Klaten dalam melakukan proses pendataan data pasien.

\section{Daftar Pustaka}

[1] 749a/MenKes/Per/XII, P. M. (1989). Tentang Rekam Medik. Jakarta: Depkes RI.

[2] Ahman, I. (2007). Panduan Klinik dan Praktek Mandiri Bidan . Bandung: Grafindo Media Pratama.

[3] Liasarie, M. (2017). Sistem Informasi Manajemen Klinik Bersalin Nurani Godean. Yogyakarta.

[4] Mulyanto, A. (2009). Sistem Informasi dan Konsep. Yogyakarta: Pustaka Pelajar.

[5] Raymond McLeod, Jr (1979) .Management Information System: A Study of Computer-Based Information Systems, Sixth Edition, Prenctice Hall.

[6] Buttle, F.(2007). Customer relationship Management, concept and tools (pp.82-83). Bayumedia.

[7] Hartono, J. (1999). Analisis dan Desain Sistem Informasi: Pendekatan Terstruktur Teori dan Praktek Aplikasi Bisnis. Yogyakarta: Andi Yogyakarta.

[8] Burch, J.G.( 1992), System, Analysis, Design, and Implementation, Boyd \& Fraser Publishing Company.

[9] John G. Burch, Jr, Felix R. Strater, Gary Grudnistski, (1979) Information Systems: Theory and Practice, Second Edition, John Wiley \& Sons.

[10]I.T. Hawryszkiewycz (1991). Introduction Systems Analysis and Design, Second Edition, Prentice Hall. 